\title{
New data on Myxobolus longisporus (Myxozoa: Myxobolidae), a gill infecting parasite of carp, Cyprinus carpio haematopterus, from Chinese lakes
}

\author{
Iva Dyková ${ }^{1,2}$, Ivan Fiala ${ }^{1,2}$ and Pin Nie $^{3}$ \\ ${ }^{1}$ Institute of Parasitology, Academy of Sciences of the Czech Republic, Branišovská 31, 37005 České Budějovice, Czech \\ Republic; \\ ${ }^{2}$ Faculty of Biological Sciences, University of South Bohemia, Branišovská 31, 37005 České Budějovice, Czech Republic; \\ ${ }^{3}$ State Key Laboratory of Freshwater Ecology and Biotechnology and Laboratory of Fish Diseases, Institute of Hydrobiology, \\ Chinese Academy of Sciences, Wuhan 430072, Hubei Province, P. R. China
}

Key words: Myxozoa, Myxobolidae, Myxobolus longisporus, morphology, pathogenicity, SSU rDNA

\begin{abstract}
The original description of Myxobolus longisporus Nie et Li, 1992, the species infecting gills of Cyprinus carpio haematopterus L., is supplemented with new data on the spore morphology and pathogenicity. Spores are elongate pyriform with pointed anterior end, $15.7(15.5-16.5) \mu \mathrm{m}$ long, 6.7 (6-8) $\mu \mathrm{m}$ wide and $5.5 \mu \mathrm{m}$ thick. Sutural ridge is straight and narrow. Mucus envelope is lacking. Two equal-sized elongate pyriform polar capsules are $8.5 \mu \mathrm{m}$ long and $2.5 \mu \mathrm{m}$ wide with convergent long axes. Polar filament coiled perpendicularly to the long axis of the capsule makes 9 (8-10) turns. Posterior end of polar capsules exceeds mid-spore by $15-20 \%$. Cyst-like plasmodia are localised in the gill secondary lamellae. The infection is described in adult big host specimens. Gross lesions manifested as dark red colouration of gill tissues were restricted to the ventral part of the first gill arches. Remarkable site specificity (apical part of secondary lamellae) was observed in the course of development of microscopic lesions. M. longisporus is characterised also on the molecular level using sequences of SSU rRNA gene. Phylogenetic analysis based on these sequences has allowed clearer phylogenetic relationships to be established with other species of the genus Myxobolus sequenced to date.
\end{abstract}

The common carp is probably the most widely distributed commercially important freshwater fish species and cultured forms of its subspecies have been introduced into many parts of the world. The updating of knowledge of its pathogens - among them myxozoan parasites in particular have frequently been recorded-is of real importance for fish biologists and pathologists.

A recently published list of parasites of two wild subspecies of the common carp Cyprinus carpio Linnaeus, 1758 (Cyprinus carpio carpio L., 1758 and C. c. haematopterus L., 1758) and the domestic common carp, C. carpio f. domestica, from regions to which the cultured form has been introduced (Baruš et al. 2002) includes 49 species of the genus Myxobolus Bütschli, 1882. The monograph on Myxozoa in the series Fauna Sinica (Chen and Ma 1998) includes 51 Myxobolus species from C. carpio and twelve from C. c. haematopterus (the latter carp subspecies is mentioned as the only host of 5 Myxobolus species; 7 Myxobolus species are listed from both subspecies). The two lists (Chen and Ma 1998, Baruš et al. 2002) have 26 Myxobolus species in common. Unfortunately, the descriptions of a half of these species dating from the first third of the 20th century or earlier do not meet the current standards and can hardly be used for a safe determination. Details on sites of infections and pathogenicity are missing for most of these species.

As part of our project on fish parasites conducted in the Hubei Province, China, we studied myxosporean parasites of cyprinid hosts. In C. c. haematopterus we found gill lesions caused by a Myxobolus species, the identity of which we studied at both morphological and molecular levels. It was revealed that this myxosporean species is a previously known parasite of $C$. carpio namely M. longisporus Nie et Li, 1992.

\section{MATERIALS AND METHODS}

A total of 15 specimens of C. c. haematopterus, 6 specimens from Lake Nuishan (size range 30 to $60 \mathrm{~cm}$ ) and 9 specimens from Lake Fu-tou (size range 30 to $78 \mathrm{~cm}$ ) (both localities in the Hubei Province), were examined in April 2002.

Small samples of gills, liver, spleen, kidney, brain and muscle tissue were examined fresh using squash preparations. Tissue samples of gills with gross lesions were fixed in fresh water Davidson's fixative and processed for histology using Histowax (Reichert Jung) as an embedding medium. Semiserial histological sections were stained with haematoxylin and eosin (H\&E) and Giemsa stains. 

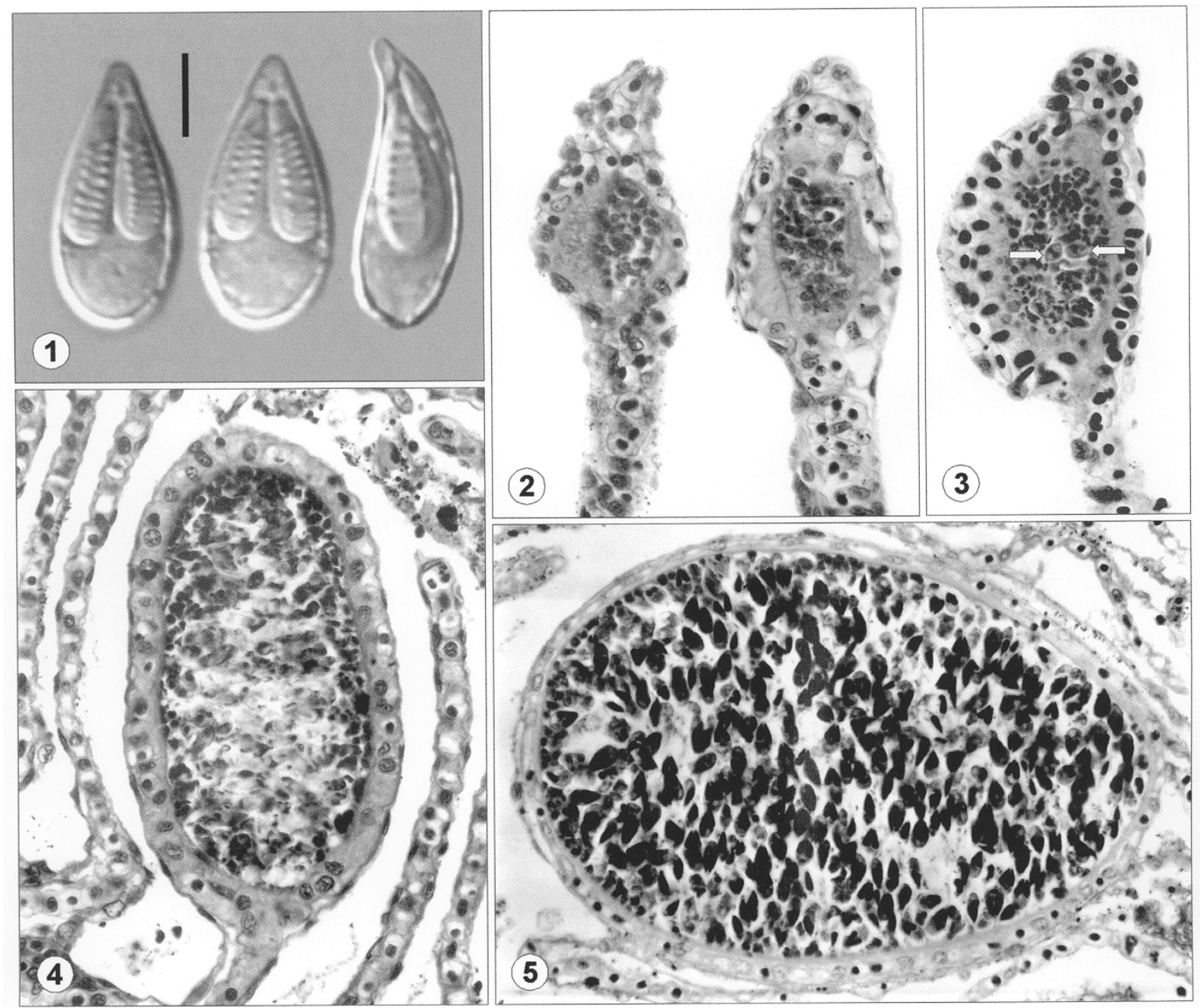

Figs. 1-5. Myxobolus longisporus and lesions caused by the development of its plasmodial stages. Fig. 1. Two fresh, mature spores in frontal view, one in lateral view. Nomarski DIC. Scale bar $=5 \mu \mathrm{m}$. Fig. 2. Early plasmodial stages developing in the capillaries of the gill secondary lamellae. Fig. 3. Plasmodium in the early spore formation stage (spores marked with arrows). Fig. 4. Advanced plasmodium with maturing spores. Remaining presporogonic stages are located on the periphery. Figs. 2-4, H\&E, $\times 410$. Fig. 5. Plasmodium packed with mature spores. Giemsa, $\times 380$. Note the differences in the host tissue surrounding periphery of developing and mature plasmodia.

Soft tissues from affected segments of gill arches were scraped off to concentrate mature spores. They were further concentrated from the gradually decomposing host tissues by repeated washing over a period of up to 7 days. The measurements of fresh spores taken with a calibrated eyepiece micrometer followed Lom and Arthur's (1989) guidelines. Representative images of spores were captured from all infected fish using Nomarski differential interference contrast (Nomarski DIC).

The extraction of DNA from pelleted spores, amplification of SSU rDNA and sequencing of amplified products followed the procedures described by Dyková et al. (2002). Sequences were aligned using Clustal X program (Thompson et al. 1997).
For preliminary phylogenetic analysis the comprehensive alignment described by Dyková et al. (2002) was used to clarify the position of new sequence of Myxobolus sp. in the myxosporean phylogenetic tree. In the final alignment (1778 nucleotide sites, 707 parsimony informative) only sequences of species closely related to the Myxobolus sp. under study were included and Myxidium lieberkuehni and M. truttae were chosen as an outgroup. Phylogenetic analyses were done using the maximum parsimony (MP), maximum likelihood (ML) and distance (minimum evolution) (ME) methods. All methods were carried out with the program package PAUP*, Version 4.0b10 (Swofford 2001). The MP analysis was done using heuristic search with random addition of taxa (10 repli- 
cations) and the ACCTRAN-option. Gaps were treated as missing data. Four different transversion/transition (Tv/Ts) ratios were tested (1:2-1:5). To obtain the best tree using ML analysis, the likelihood ratio test (LRT) implemented in Modeltest v. 3.06 (Posada and Crandall 1998) was used, in which the GTR $+\mathrm{G}+\mathrm{I}$ model of evolution was found to fit the data best. The distance method was executed using heuristic search with the minimum evolution as the objective setting and the Kimura two-parameter (K2P) substitution model. Clade support was assessed with bootstrapping (1000 replicates).

\section{RESULTS}

Gross lesions of the same type were found in the gills of 14 out of the 15 examined carps. Spores with consistent morphology were found in all infected specimens. In some tissue samples examined in fresh prevailed plasmodia in early stage of their development. Comparison of fresh spores and histological examination proved identity of gill infections in all examined specimens. Comparison of spore morphology with published descriptions of Myxobolus species allowed to identify the agent as Myxobolus longisporus Nie et Li, 1992. The results of phylogenetic analyses based on SSU rRNA gene sequences clearly distinguished $M$. longisporus from M. pseudokoi. As the original description of $M$. longisporus is incomplete, the species is redescribed below and compared with selected Myxobolus species whose spores have a similar morphology.

\section{Myxobolus longisporus $\mathrm{Nie}$ et $\mathrm{Li}, 1992$}

Fig. 1

Morphology of spores. Fresh spores (light microscopy, $\mathrm{n}=20$ ) elongate pyriform with pointed anterior end, 15.7 (15.5-16.5) $\mu \mathrm{m}$ long, 6.7 (6-8) $\mu \mathrm{m}$ wide and $5.5 \mu \mathrm{m}$ thick. In sutural view, anterior end slightly bent. Sutural ridge straight and narrow. Mucus envelope lacking. Two equal-sized elongate pyriform polar capsules $8.5 \mu \mathrm{m}$ long and $2.5 \mu \mathrm{m}$ wide, with convergent long axes. Polar filament coiled perpendicularly to the long axis of the capsule with 9 (8-10) turns. Intercapsular process not visible. Posterior end of polar capsules exceeding mid-spore by $15-20 \%$.

Vegetative stages. Cyst-like plasmodia localised in the gill secondary lamellae.

H o s t: Cyprinus carpio haematopterus Linnaeus, 1758.

L o c a 1 i t i e s: Lakes Nuishan and Fu-tou, Hubei Province, China.

Site of infection: Gills.

P r e v a l e n c e : 14 of 15 fish examined (93\%) infected.

Pathogenicity. Gross lesions were manifested in severely infected fishes as consistent colour changes of gills. Affected ventral part of the first gill arch was dark red coloured. Histological examination revealed that lesions developed together with plasmodial stages in the gill secondary lamellae (Figs. 2-5). Remarkable site specificity was observed in early stages of the development of plasmodia, whose localisation was always

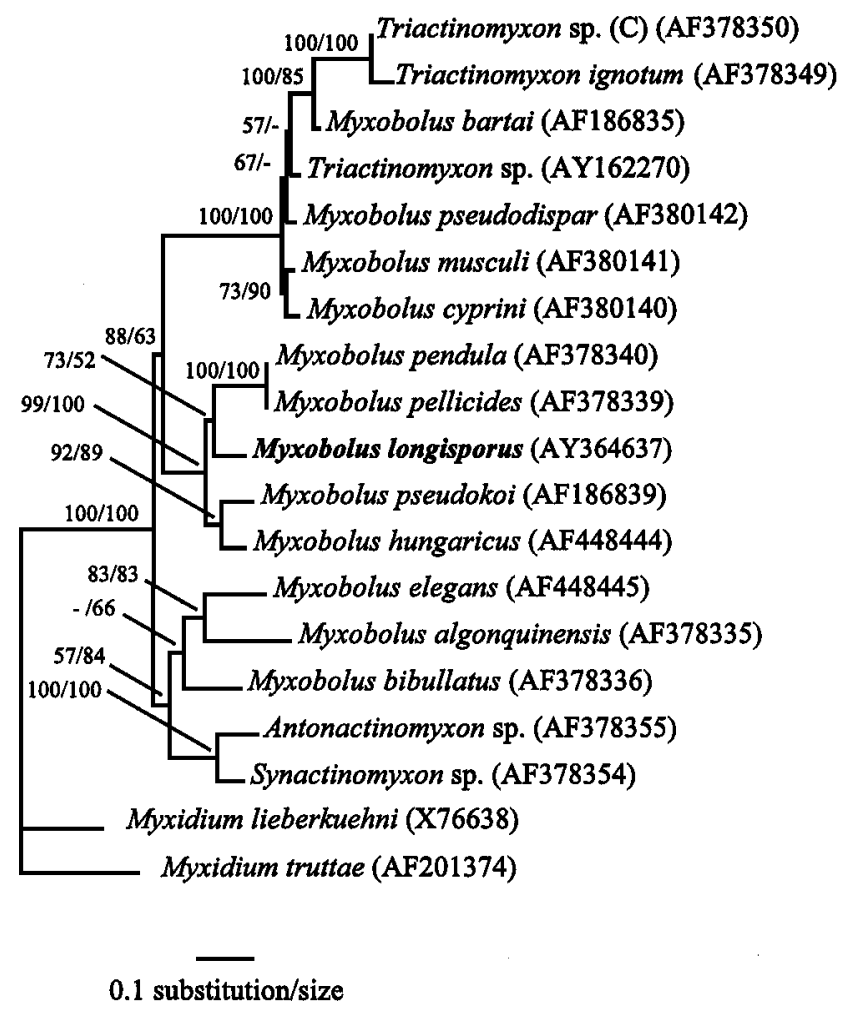

Fig. 6. Maximum likelihood tree of the SSU rRNA sequences of Myxobolus spp. rooted at Myxidium lieberkuehni and M. truttae $(-\ln =11928.1291, \alpha$ shape parameter $=0.67803$, PINVAR $=0.16264)$. Bootstrap values $(\mathrm{ML} ; \mathrm{MP} \mathrm{Tv} / \mathrm{Ts}=1: 2)$ are indicated for the nodes gaining more than $50 \%$ support. The distance scale is given under the tree. GenBank accession numbers are in parentheses.

restricted to the capillaries in apical part of secondary lamellae (Figs. 2-4). One plasmodium only developed in each secondary lamella. As observed from sectioned material, the volume of plasmodia increased approximately ten-fold from those smallest in an initial stage (Figs. 2, 3) to largest plasmodia being packed with mature spores (Fig. 5). Late-stage infections were associated with more pronounced gill lesions including adhesion, fusion and necrosis of adjacent lamellae. The extent of gill damage and its supposed impact on gill function increased with increasing numbers and size of plasmodia developing within the secondary lamellae.

Molecular characterisation. The SSU rRNA gene sequence of Myxobolus longisporus comprises 2046 bp and $\mathrm{G}+\mathrm{C}$ content is $46.3 \%$. The sequence was deposited in GenBank under accession number AY 364637. Fig. 6 shows a maximum likelihood tree $(-\ln =$ 11928.1291) of SSU rRNA sequences of the closest relatives of $M$. longisporus. The phylogenetic analyses clearly distinguished $M$. longisporus from all Myxobolus species sequenced to date and positioned it to the well bootstrap supported clade of M. pendula, M. pellicides, M. hungaricus and M. pseudokoi. ML and ME analyses suggested sister relation of $M$. longisporus to 
Table 1. Biometrical data (in $\mu \mathrm{m}$ ) on Myxobolus species selected for comparison.

\begin{tabular}{|c|c|c|c|c|c|c|}
\hline \multirow{2}{*}{$\begin{array}{l}\text { Myxobolus spp. } \\
\text { Host species }\end{array}$} & \multicolumn{3}{|c|}{ Spores } & \multicolumn{2}{|c|}{ Polar capsules } & \multirow{2}{*}{ References } \\
\hline & Length (L) & Width (W) & Thickness & $\mathrm{L} \times \mathrm{W}$ & Coils & \\
\hline $\begin{array}{l}\text { M. longisporus } \mathrm{Nie} \text { et } \mathrm{Li}, 1992 \\
\text { Cyprinus carpio haematopterus } \mathrm{L} .\end{array}$ & $\begin{array}{c}15.7 \\
(15.5-16.5) \\
\end{array}$ & $6.7(6-8)$ & 5.5 & $8.5 \times 2.5$ & $9(8-10)$ & Present study \\
\hline $\begin{array}{l}\text { M. longisporus Nie et Li, } 1992 \\
\text { Cyprinus carpio L. }\end{array}$ & 17.5 & $6.5-7.0$ & 6.0 & $7.5-8.2 \times 2.0$ & unspecified & Nie and Li (1992) \\
\hline $\begin{array}{l}\text { M. longisporus } \mathrm{Nie} \text { et } \mathrm{Li}, 1992 \\
\text { Cyprinus (cyprinus) carpio L. }\end{array}$ & $16.0-17.5$ & $6.5-7.0$ & 6.0 & $7.5-8.2 \times 2.0$ & unspecified & Chen and Ma (1998) \\
\hline $\begin{array}{l}\text { M. koi Kudo, } 1919 \\
\text { Cyprinus carpio L. }\end{array}$ & $14.0-16.0$ & $8.0-9.0$ & $5.0-6.0$ & $\begin{array}{c}8.0-9.0 \times \\
2.5-3.0\end{array}$ & 11 depicted & Kudo (1919) \\
\hline $\begin{array}{l}\text { M. koi Kudo, } 1919 \\
\text { Cyprinus carpio L. (var. koi) }\end{array}$ & $\begin{array}{c}14.12 * \\
(11.70-16.07)\end{array}$ & $\begin{array}{c}7.14 * \\
(6.03-8.01) \\
\end{array}$ & $\begin{array}{c}6.61 * \\
(5.13-7.83) \\
\end{array}$ & $7.48^{*} \times 2.96^{*}$ & 9 & $\begin{array}{c}\text { Crawshaw and } \\
\text { Sweeting (1986) }\end{array}$ \\
\hline $\begin{array}{l}\text { M. pseudokoi Li et Desser, } 1985 \\
\text { Notropis cornutus Mitchill }\end{array}$ & $\begin{array}{c}13.5 \\
(11.5-14.0)\end{array}$ & $\begin{array}{c}6.5 \\
(6.0-7.0)\end{array}$ & 5.0 & $\begin{array}{l}6.5(6.0-7.5) \times \\
2.5(2.0-3.0)\end{array}$ & $6-7$ & Li and Desser (1985) \\
\hline $\begin{array}{l}\text { M. pseudokoi Li et Desser, } 1985 \\
\text { Notropis cornutus Mitchill }\end{array}$ & $\begin{array}{c}13.2 \\
(12.4-14.3)\end{array}$ & $\begin{array}{c}6.4 \\
(5.6-7.0) \\
\end{array}$ & $\begin{array}{c}5.4 \\
(5.0-6.1)\end{array}$ & $\begin{array}{c}6.2(5.4-7.0) \times \\
2.4(2.0-2.8)\end{array}$ & $6-8$ & $\begin{array}{l}\text { Salim and Desser } \\
(2000)\end{array}$ \\
\hline
\end{tabular}

* median

M. pendula and M. pellicides with rather high bootstrap support ( $73 \%$ and $81 \%$, respectively). MP analysis $\mathrm{Tv} / \mathrm{Ts}=1: 2$ (3128 steps) revealed the same branching pattern but with low bootstrap support (52\%). MP analyses $\mathrm{Tv} / \mathrm{Ts}=1: 3$ (4042 steps) and $\mathrm{Tv} / \mathrm{Ts}=1: 4$ (4956 steps) revealed the sister relation of $M$. longisporus to M. hungaricus and M. pseudokoi with bootstrap support lower than 50\%. MP analysis Tv/Ts $=1: 5$ (6595 steps) resulted into two trees with the same length and both topologies differed in the same way as described above for ML and MP (Tv/Ts = 1:3), respectively.

\section{DISCUSSION}

As seen from measurements collected in Table 1, Myxobolus longisporus and M. koi are discriminated from $M$. pseudokoi by having the greater length of spores and capsules with more coils of the polar filament. Nie and Li (1992) mentioned in their original description that spores of $M$. longisporus "look like spores of $M$. koi but they are larger, slender and elegant, without any folds on the shell valves". The number of coils of polar filament was not given in the original description of $M$. longisporus. According to the original description by Kudo (1919), spores of M. koi have no sutural markings or folds on shell valves. For M. longisporus, inconsistencies were found among measurements given in the original description, a line drawing (Nie and Li 1992) and the characters of the same species given in the key to species of the genus Myxobolus in Chen and Ma (1998). While in the original description the authors state that elongate club-shaped polar capsules of $M$. longisporus occupy about half length of the spore, in their line drawing the polar capsules exceed by one quarter the midpoint of the spore length. According to Chen and Ma's key (1998), the polar capsule length of $M$. longisporus is smaller than or equal to half of the spore length. Despite the inconsistencies mentioned above, the agent of gill lesions
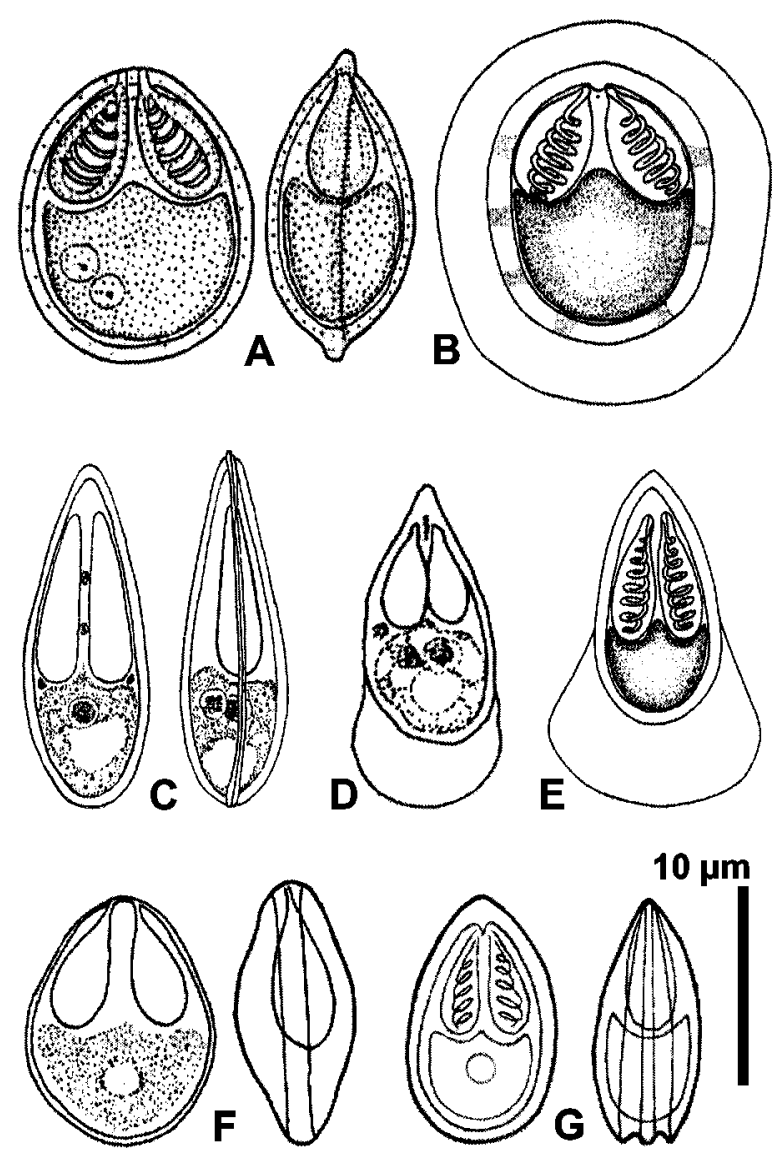

Fig. 7. Spores of three Myxobolus species closely related in their SSU rRNA gene sequences to M. longisporus $\mathrm{Nie}$ et $\mathrm{Li}$, 1992. A - M. pendula after Guilford (1967); B - M. pendula after Salim and Desser (2000); C - M. longisporus after Nie and Li (1992); D - M. pseudokoi after Li and Desser (1985); E - M. pseudokoi after Salim and Desser (2000); F - M. hungaricus after Jaczó (1940); G - M. hungaricus after ElMansy and Molnár (1997). The line drawings from original papers are reproduced to the same scale. 
described in this study was identified as $M$. longisporus. The type host of this species was specified in the original description as C. carpio L.; however, infections appear to be restricted to subspecies $C$. c. haematopterus. It is clear from the literature that the correct zoological nomenclature reflecting the concept of three subspecies of C. carpio and their domesticated forms (C. c. carpio, C. c. haematopterus and C. c. viridiviolaceus - see Baruš et al. 2002) has not been applied rigorously.

The difficulties that we encountered in Myxobolus species identification have been widely recognised (Lom and Arthur 1989, Landsberg and Lom 1991, Salim and Desser 2000, Kent et al. 2001, Dyková et al. 2002). The large number of named species, inadequacy of their descriptions and lack of objective documentation (photomicrographs) contribute to this.

The results of our analyses clearly distinguished $M$. longisporus from $M$. pseudokoi supporting indirectly the diagnosis of the species under study. Unfortunately, the sequence of SSU rRNA gene of $M$. koi, another species similar to $M$. longisporus that was described from cyprinid hosts, was not available for analysis

Although Salim and Desser (2000) in their phylogenetic systematics of Myxobolus species concluded that the species with similar spore morphology are more closely related to each other than to the species with distinct morphology and suggested that spore morphology can reflect historical associations among taxa, the results of our phylogenetic analyses brought together species with quite different spore morphology: $M$. pendula Guilford, 1967 and M. pellicides Li et Desser, 1985 with M. longisporus, and M. pseudokoi with $M$. hungaricus Jaczó, 1940 (see Fig. 7). The morphology of
M. pseudokoi and M. hungaricus differs substantially; nevertheless, a phylogenetic analysis inferred from sequences of SSU rRNA gene indicates that they had a common ancestor.

The sequences of $M$. pellicides and $M$. pendula were included in our analysis even though Salim and Desser (2000) synonymised these species. They found that they have similar spore morphology, an identical host, the same tissue specificity, and a high sequence similarity (confirmed in our data set). In addition, they called in question taxonomic reliability of the mucus envelope (the only character that Li and Desser (1985) used to distinguish these two species), because it was present in some isolates but absent in others.

Several recent review articles have concluded that the degree of sequence divergence is difficult to interpret in a taxonomic context (Carreno et al. 2001, Kunz 2002). Nevertheless, SSU rRNA gene sequences have been widely used in searching for evidence of distinct species as well as in inferring phylogenetic relationships within genera. The same applies for Myxozoa. In the most comprehensive study by Kent et al. (2002), SSU rRNA gene sequences of 21 Myxobolus species were included and the need to analyse more data was stressed. SSU rRNA gene sequences of 41 named and 3 unnamed $M y$ xobolus species were available in the GenBank in early March 2003.

Acknowledgements. The authors are grateful to the Ministry of Education, Youth and Sports of the Czech Republic for financial support of this research (Project KONTAKT ME 424 and Project No. MSM 12300003), and to the National Natural Science Foundation of China (Project No. 30025035).

\section{REFERENCES}

BARUŠ V., PEŇÁZ M., KOHLMANN K. 2002: Cyprinidae 2. Part III: Carassius to Cyprinus. Gasterosteidae. In: P.M. Bănărescu and H.-J. Paepke (Eds.), The Freshwater Fishes of Europe. Vol. 5/III. Aula-Verlag, Wiebelsheim, pp. 85179.

CARRENO R.A., POKORNY N.J., LEE H., TREVORS J.T., De GRANDIS S.A. 2001: Phenotypic and genotypic characterization of Cryptosporidium species and isolates. J. Ind. Microbiol. Biotechnol. 26: 95-106.

CHEN C., MA C. 1998: Fauna Sinica. Myxozoa, Myxosporea. Science Press, Beijing, China, 993 pp.

CRAWSHAW M.Z., SWEETING R.A. 1986: Myxobolus koi Kudo, 1919: a new record for Britain. J. Fish Dis. 9: 465467

DYKOVÁ I., FIALA I., NIE P. 2002: Myxobolus lentisuturalis sp. n. (Myxozoa: Myxobolidae), a new muscleinfecting species from the Prussian carp, Carassius gibelio from China. Folia Parasitol. 49: 253-258.

EL-MANSY A., MOLNÁR K. 1997: Development of Myxobolus hungaricus (Myxosporea: Myxobolidae) in oligochaete alternate hosts. Dis. Aquat. Org. 31: 227-232.
GUILFORD H.G. 1967: Myxosoma pendula n. sp. (Protozoa, Myxosporida) from the creek chub Semotilus atromaculatus. J. Protozool. 14: 196-198.

JACZÓ I. 1940: Investigation on myxosporidians of Lake Balaton fishes I. A Magyar Biologiai Kutatóintézet Munkáiból 12: 277-289. (In Hungarian.)

KENT M.L., ANDREE K.B., BARTHOLOMEW J.L., ElMATBOULI M., DESSER S.S., DEVLIN R.H., FEIST S.W., HEDRICK R.P., HOFFMANN R.W., KHATTRA J., HALLET S.L., LESTER R.J.G., LONGSHAW M., PALENZUELA O., SIDDALL M.E., XIAO C. 2001: Recent advances in our knowledge of the Myxozoa. J. Eukaryot. Microbiol. 48: 395-413.

KUDO R.R. 1919: Studies on Myxosporidia. III. Biol. Monogr. 5: 241-503.

KUNZ W. 2002: When is a parasite species a species? Trends Parasitol. 18: 121-124.

LANDSBERG J.H., LOM J. 1991: Taxonomy of the genera Myxobolus/Myxosoma group (Myxobolidae: Myxosporea), current listing of species and revision of synonyms. Syst. Parasitol. 18: 165-186. 
LI L., DESSER S.S. 1985: The protozoan parasites of fish from two lakes in Algonquin Park, Ontario. Can. J. Zool. 63: $1846-1858$.

LOM J., ARTHUR J.R. 1989: A guideline for the preparation of species description in Myxosporea. J. Fish Dis. 12: 151-156.

NIE D.-S., LI L.-X. 1992: On the myxosporidians of freshwater fishes from lake Huama, Hubei province: II. Descriptions of new species (Myxosporea: Bivalvulida). Acta Zootaxonom. Sin. 17: 133-150.

POSADA D., CRANDALL K.A. 1998: Modeltest: testing the model of DNA substitution. Bioinformatics 14: 817-818.

Received 25 April 2003
SALIM K.Y., DESSER S.S. 2000: Descriptions and phylogenetic systematics of Myxobolus spp. from cyprinids in Algonquin Park, Ontario. J. Eukaryot. Microbiol. 47: 309311.

SWOFFORD D.L. 2001: PAUP*: Phylogenetic Analysis Using Parsimony ( ${ }^{*}$ and other methods), version $4.0 \mathrm{~b} 10$. Sinauer Associates, Sunderland, MA, USA.

THOMPSON J.D., GIBSON T.J., PLEWNIAK F., JEANMOUGIN F., HIGGINS D.G. 1997: The CLUSTAL_X windows interface: flexible strategies for multiple sequence alignment aided by quality analysis tools. Nucleic Acids Res. 25: 4876-4882.

Accepted 25 July 2003 